\title{
Structure of Rural Income in Pakistan: Some Preliminary Estimates
}

\author{
FAIZ MOHAMMAD and GHULAM BADAR*
}

\section{INTRODUCTION}

The main objective of this paper is to study the rural income distribution in Pakistan by determining income accruing to farm and non-farm households from various assets held by them. Most of the existing literature on income distribution in Pakistan $[3 ; 4 ; 8 ; 10 ; 12 ; 14 ; 17]$ focuses either on aggregate income or only on income from crops and classifies rural households by their income level. It ignores the internal structure of income as well as one of the main distinguishing features of rural households, namely their relation to land. ${ }^{1}$ In a developing country, however, the internal structure of income is likely to change with changes in the level of income. It is therefore important to assess the contribution of an individual factor (asset) to the overall income of a household and its impact on income inequality. Moreover in the case of Pakistan where land is becoming increasingly scarce for small farmers $[7 ; 11]$ it should be interesting to know how these farmers are trying to "fight back" the pressure on their land with alternative sources of income.

The present study, therefore, has two main objectives: (i) to estimate incomes of 'farm' and 'non-farm' households in Pakistan on the basis of the different assets held by them; and (ii) to study income inequality using data from (i) and compare it with the inequality in the distribution of assets.

The paper is divided into three main sections. Section I explains the methodology followed in this paper for estimating rural income as well as the level of inequality in its distribution. Empirical results are presented and analyzed in Section II. A few tentative conclusions emerging from our findings are presented in Section III.

*The authors are now Senior Research Economist and Associate Staff Economist, respectively, at the Pakistan Institu te of Development Economics, Islamabad (Pakistan).

${ }^{1}$ Studies by Ayub [1] and Ercelawn [5] may be exceptions to this. However, Ayub's study used Household, Income and Expenditure Survey (HIES) data up to 1971-72 which obviously may not be relevant today. Moreover the asset's classification given in HIES is too general to help to properly identify rural assets. Ercelawn's study, though rigorous in approach, was on the other hand, based on the data of a sample survey of a few villages. A usual problem with the income data obtained through questionnaires is that the respondents have the tendency to misreport their incomes. 


\section{METHODOLOGY AND DATA}

\section{Estimation of Rural Income}

Rural Households in Pakistan observably derive their incomes from more than one source. Net Income $(Y)$ of a household category ${ }^{2} i$ could therefore be expressed as a sum of the net incomes from different sources (assets) as shown in equation (1).

$$
Y_{i}=C I_{i}+M I_{i}+M L_{i}+L I_{i}+L B_{i}-C D_{i} \quad \ldots \quad \ldots
$$

where $C I$ stands for income from major and minor crops, $M I$ for income from machinery, $M L$ for income from milch animals, $L I$ for income from livestocks other than milch animals, $L B$ for income from labour offered to other households in agricultural and non-agricultural sectors; and $C D$ for cost of debt. (Since debt is a liability on a household, its costs should be deducted from the overall income to arrive at the "true" net income.)

Income estimates using equation (1) were obtained for three years, viz. 1960, 1972 and 1980. These were the only years for which the data required to calculate equation (1) were available in Pakistan. Since availability of the required data was one of the major constraints on the type of methods we could use to estimate equation (1), a little discussion of the nature of the data needed for our purpose is in order and is given below as a background to our methodology which is discussed later.

In Pakistan, the Census of Agriculture (henceforth Census only) [18] is perhaps the only published document which provides detailed information on the assets and liabilities of rural households. This document published three times so far (in 1960, 1972 and 1980) is based on a large representative sample covering almost all the areas in Pakistan and is a major source of data on the rural economy. Unfortunately, however, the methodology of data collection followed in the 1960 Census was not the same as the one followed in the 1972 or 1980 Census $^{3}$ so that some adjustments in the 1960 data is necessary if all the three censuses are to be made comparable. Such an adjustment was made by Hussain [7] in the data on land alone, but as comparable information on "non-land assets" was not available to us from any source, similar adjustments for other assets have not been possible for this study. We have, therefore, estimated equation (1) on the basis of unadjusted census data on rural assets and liabilities. Like all other data in Pakistan, the censuses data are also defective but we know of no other data that could be considered more reliable.

${ }^{2}$ Most of the data on income distribution in Pakistan classify households in different categories based on their income levels or land holdings. The estimates in this paper, therefore, refer to these categories and not to individual households.

${ }^{3}$ See Hussain [7] for this point and for the method used by him to adjust the data of the 1960 Census.
To estimate equation (1), we also required data on costs and prices of different agricultural items. This information is hardly available from any single source in Pakistan. We, therefore, gathered this information from such sources as [2], [15], [16], [19], [20], [21], [24] and [25].

Now, to estimate rural income, it was necessary to attach suitable values to the flow of outputs from the assets held by different groups. Since it was not always easy to determine what proportion of the gross value added by an asset was retained by the household itself and what proportion of it was paid to (or received from) others in the form of "rent", and as systematic and precise data on inter-farm productivity differences are hardly available in Pakistan, ${ }^{4}$ some indirect measures had to be used to capture this determinant of income. The steps involved in computing these components of income were so many that it may not be possible to elaborate all of them in this brief paper. Therefore, only a brief description of those steps is presented below.

\section{Income from Crops $(\mathrm{CI})$}

To estimate income from crops, first of all the net value added by major and minor crops was distributed among the farm groups in proportion to their cropped area. $^{5}$ This amount was then adjusted for tenancy rent depending on the amount of cropped area rented in or rented out by a given farm group. ${ }^{6}$ To do so, we obtained estimates of what may be called 'tenancy income' which was equal to onehalf of the net value added by the area cultivated by tenants (both share-croppers and lease-holders).

\section{Income from Machinery (MI)}

This income was taken to be the sum of incomes from three types of farm machinery: viz. tubewells, tractors and threshers. Income from other minor farm equipment was ignored as its valuation posed serious problems. Also, for 1960 the Census did not contain data on tractors or threshers in the list of farm machinery probably because they were hardly used by farmers at that time. Therefore, for thi year, income from tubewells alone could be estimated as a proxy for $M I$ which makes

${ }^{4}$ Studies on inter-farm productivity differences in Pakistan so far have come up with contradictory results. According to some, large farms are more productive than the small ones $[9 ; 10]$, whereas according to some others $[3]$ the opposite is true. Moreover, the magnitudes of inter-farm productivity differences found by one study are not comparable with those found by others.

${ }^{5}$ Cropped area by incorporating the effect of cropping intensity at least partially takes care of the inter-farm productivity differences.

${ }^{6}$ Data on area rented-out for 1960 and 1972 were computed on the basis of some indirect information given in the Censuses of the respective periods. 
the 1960 estimates of $M I$ somewhat less comparable with those for the other two periods. To estimate income from different types of farm machinery the general approach used was as follows :

$$
M I_{i j}=\left(S U_{i j}\right)\left(N V_{i}\right)+\left(M R O_{i}\right)-\left(N V_{i}\right)-\left(M R I_{i j}\right)\left(P_{i}\right) \ldots \ldots
$$

where $S U$ stands for the acreage served by the owner's own machinery; $N V$ for net value (per acre) of using the $j$ th machinery and is equal to $\left(P_{j}-A O C_{i}-D_{i}\right): M R O$ the acreage served by the machinery rented out; $M R I$ for the acreage served by machinery rented in; $P$ for cost of using a machinery on one acre; $A O C$ for average operating $\operatorname{cost} ; D$ for depreciation cost (taken as $10 \%$ of the total value of asset $)^{7} ; i$ for different farm groups $(=1, \ldots \ldots 10)$; and $j$ for different machinery items 1,2 and 3 .

In the right-hand side of equation (2) the first component captures the imputed value of owning a farm equipment for own use. The other two components capture the rent received or paid by a farm group. In the cases of those farm groups who rented-out machinery, the third component would become zero.

\section{Income from Milch Animals (ML)}

This component of income was relatively easy to calculate. The net value of the total milk produced in the country was distributed among different groups in proportion to the number of the milch animals owned by them. To calculate the net value of milk, the cost of production was assumed to be 50 percent of the gross revenue, whereas the rural share was taken to be 90 percent of the total production [25]. In this way, the rural share of the net revenue from milk - the total value of milk produced $\times 0.9 \times 0.5$

\section{Income from Livestock (LI)}

This includes incomes from beef, mutton, and poultry. The total production of these items was used to calculate the net income of each group. For beef, the distribution among groups was done in proportion to the number of work animals, dry cows and buffaloes owned by them. Income from mutton was distributed in proportion to the 'number of sheep and goats owned', whereas the value of poultry products (meat and eggs) was distributed according to the 'poultry birds owned' by each category. ${ }^{8} \quad$ To arrive at the rural share of net revenue from livestocks the costs

${ }^{7}$ This depreciation rate is widely used, particularly in studies on tubewells in Pakistan. See $[2 ; 15]$ for this.

${ }^{8}$ For 1980 , the distribution of poultry birds was not available. Therefore, for this purpose, the pattern of distribution of poultry birds in 1960 and 1972 was used to distribute the income from poultry among different groups. of production were taken to be equal to one-third of the gross revenue and the rural share of production was assumed at be equal to 80 percent of the total production [25]

\section{Income from Labour (LB)}

Estimation of this component of income posed a number of additional problems not encountered in other cases. This problem mainly sprang from the difference in the extent of the coverage of labour in the different censuses. The 1980 Census, for example, contained almost all the necessary information needed to calculate the income from labour. For 1972, however, a few missing pieces of information had to be computed from other sources such as the 25 Years of Pakistan in Statistics [22]. However, it was not possible at all to calculate comparable income from the 1960 Census data. Other data sources were also not very helpful. For 1960, therefore, data were generated by using ratios of income from labour to total income for the other two periods. ${ }^{9}$ For 1972 and 1980, the method used was to calculate net employment income by substracting labour costs paid by a group on hiring the permanent and the casual labour in a year from its total employment earnings from agricultural and non-agricultural sectors. For this purpose, we used the wage rates of unskilled rural workers for the agricultural sector and weighted averages of wages in the manufacturing sector for the non-agricultural sector. ${ }^{10}$

\section{Cost of Debt (CD)}

This was calculated by employing a weighted average of the interests charged on different types of loans. Thus, for the $i$ th farm group the cost of debt was:

$$
\left.C D_{i}=\begin{array}{l}
\text { Debt owned by the } i \text { th } \\
\text { farm category. }
\end{array} \times \quad \begin{array}{l}
\text { Weighted average } \\
\text { interest rate }
\end{array}\right\}
$$

\section{Measuring Inequality in Rural Income}

Using income estimates based on the methodology stated above, we calculated Gini-coefficients as a measure of rural income inequality. ${ }^{11}$ Gini-coefficients based on data for distribution of assets, were also obtained so that they could be compared with those based on income data. No attempt was, however, made to estimate other measures of inequality as our purpose here was to keep our preliminary findings relatively simple and comparable with those of earlier studies on the subject.

${ }^{9}$ This may sound an ad hoc method, but the ratios for 1972 and 1980 were so close that it would have made practically no difference if one were to use either one of the two or a ratio derived from their time trend.

${ }^{10}$ This might have understated the income from employment of large farm groups, whose family members, if employed in non-agricultural sector, were likely to be in highly paid jobs instead of earning an average wage in the manufacturing sector. 


\section{EMPIRICAL RESULTS}

In this section, we present estimates of (a) rural income and (b) income inequality.

\section{(a) Rural Income}

Estimates of rural household income and the percentage share of each asset in it, are presented in Tables 1-3. Out of the ten categories for which data are presented here, nine belong to farm households whereas the tenth relates to livestock households. $^{12}$ Table 4 shows the growth rates of income of different groups. All the figures are based on current prices.

The main features of these estimates are as follows:

1. Household income in 1960 ranged between Rs. 711 and Rs. 12,612 with the average amounting to Rs. 1,723 for all households and to Rs. 1,510 13 for farm households. In 1972 , the range was from Rs. 1,643 to Rs. 63,419 whereas the averages for all households and farm households were Rs. 4,099 and Rs. 4,455, respectively. In 1980, the household income ranged between Rs. 4,982 and Rs. 2,17,086 with the averages for all households and farm households stood at Rs. 13,245 and Rs. 14,771, respectively.

2. The major contribution to overall income is made by the income from crops, the average share of which in 1960 was 47.3 percent in the case of all households and 57.88 percent in the case of farm households. The corresponding figures were 58.06 percent and 73.85 percent, for 1972 , and 53.67 percent and 70.57 percent for 1980 . These estimates show that the share of the income from crops in the household income increased considerably between 1960 and 1972 and then came down slightly by 1980. The increase in the share of the income from crops in the Sixties may be attributed to the relatively high growth in agricultural productivity in that decade.

Income from crops, however, does not seem to be as significant for small farms as it is for the large ones. Besides 'livestock households' whose income from crops is nil, the share of the income from crops in the in comes of farm categories with less 2.5 acres was between 7.31 percent and 23.67 percent in 1960 , and between 16.68 percent and 36.86 percent in 1980 For small farm households, incomes from labour and livestock are much more important. Income from labour accounted for 73.65 percent

${ }^{12}$ In the census data this category includes all the non-farm households and the 'nonoperating land-owners'. However except in 1972 the breakdown of this category was no available. Moreover even if one could separate the non-operating land-owners from 'livestock households' to get pure 'non-farm households' it was not possible to do the same for their corresponding assets. It was therefore decided to keep 'livestock households' as one category.

${ }^{13}$ The term All Households includes both Farm Households and Livestock Households.

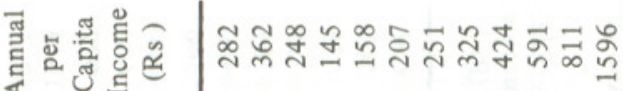

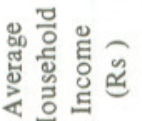

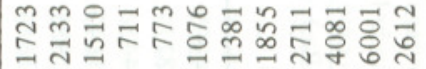
Еั

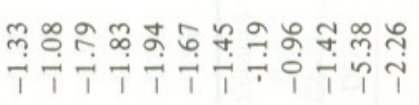

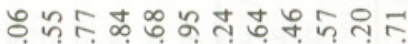

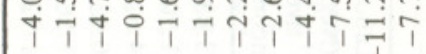

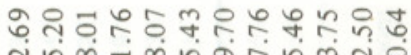
สูก

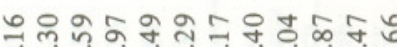

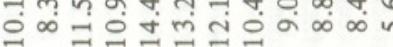

ธิต ำ

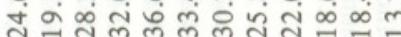

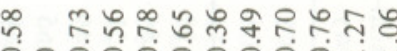
000

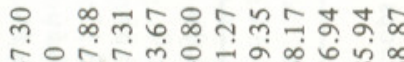

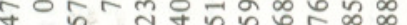
ஸิ

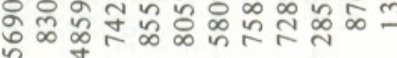

흥

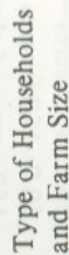


Rural Household Income by Source and by Farm Size 1972

\begin{tabular}{|c|c|c|c|c|c|c|c|c|c|c|c|}
\hline \multirow{3}{*}{$\begin{array}{l}\text { Type of Households } \\
\text { and Farm Size }\end{array}$} & \multirow{3}{*}{$\begin{array}{l}\text { Number } \\
\text { of } \\
\text { House- } \\
\text { holds }\end{array}$} & \multicolumn{5}{|c|}{ Percentage of Household Income from } & \multirow{2}{*}{\multicolumn{2}{|c|}{$\begin{array}{l}\text { Cost Borne as \% of } \\
\text { - Household Income } \\
\text { for }\end{array}$}} & \multirow{3}{*}{$\begin{array}{l}\text { Household } \\
\text { Income } \\
\text { Net of } \\
\text { Costs } \\
(\%)\end{array}$} & \multirow{3}{*}{$\begin{array}{l}\text { Average } \\
\text { Household } \\
\text { Income } \\
\text { (Rs) }\end{array}$} & \multirow{3}{*}{$\begin{array}{c}\text { Annual } \\
\text { per } \\
\text { Capita } \\
\text { Income } \\
\text { (Rs ) }\end{array}$} \\
\hline & & \multirow{2}{*}{ Crops } & \multirow{2}{*}{$\begin{array}{c}\text { Machi- } \\
\text { nery }\end{array}$} & \multirow{2}{*}{$\begin{array}{c}\text { Milch } \\
\text { Animals }\end{array}$} & \multirow{2}{*}{$\begin{array}{l}\text { Live- } \\
\text { stock } \\
\text { Except } \\
\text { Milch } \\
\text { Animals }\end{array}$} & \multirow{2}{*}{ Labour } & & & & & \\
\hline & & & & & & & $\begin{array}{l}\text { Labour } \\
\text { (Nega- } \\
\text { tive } \\
\text { Income) }\end{array}$ & $\begin{array}{l}\text { Debt } \\
\text { (Nega- } \\
\text { tive } \\
\text { Income) }\end{array}$ & & & \\
\hline 1. $\mathrm{Al}$ & 514508 & 58.06 & 2.27 & 16.25 & 6.32 & 21.81 & -3.88 & -0.88 & 10 & 4099 & 631 \\
\hline 2. Livestock Households & 1531650 & 0 & 0. & & & 74 & -1 & . & & 3114 & 507 \\
\hline 3. Farm Households & 3992858 & 73.85 & 4.27 & 08 & 6.17 & 7.68 & -4.51 & -0.97 & 1( & 4455 & 675 \\
\hline Under 1.0 acre & 153331 & 13.57 & 0.49 & 29.15 & 7.36 & 51.25 & -0.85 & -1.16 & 10 & 1643 & 299 \\
\hline $1.0-2.5$ acres & 367284 & 45.60 & 0.65 & 20.15 & 8.56 & 27.61 & -1.56 & -1.11 & 10 & 1985 & 354 \\
\hline $2.5-5.0$ acres & 546412 & 58.85 & 0.49 & 20.27 & 8.03 & 15.15 & -1.92 & -0.87 & 10 & 2654 & 450 \\
\hline $5.0-7.5$ acres & 593269 & 61.98 & 0.47 & 21.93 & 9.09 & 9.53 & -2.15 & -0.86 & 10 & 3388 & 546 \\
\hline $7.5-12.5$ acres & 968261 & 69.92 & 0.66 & 18.31 & 7.14 & 7.54 & -2.63 & -0.85 & 10 & 3768 & 580 \\
\hline $12.5-25.0$ acres & 867880 & 77.43 & 2.14 & 14.81 & 5.64 & 5.17 & -4.28 & -0.93 & 10 & 4855 & 683 \\
\hline $25.0-50.0$ acres & 350397 & 83.74 & 5.28 & 10.26 & 5.39 & 3.44 & -7.06 & -1.06 & 100 & 7141 & 927 \\
\hline $50.0-150.0$ acres & 132072 & 87.71 & 9.12 & 8.30 & 3.92 & 2.24 & -10.05 & -1 . & 100 & 13398 & 1614 \\
\hline 150 acres and above & 19750 & 98.74 & 4.21 & 2.93 & 1.37 & 0.64 & -7.14 & -0.84 & 100 & 63419 & 6747 \\
\hline
\end{tabular}

Source: Computations based on data from Pakistan $[18 ; 19 ; 20$ and 21$]$.

Table 3

Rural Household Income by Source and by Farm Size in Pakistan 1980

\begin{tabular}{|c|c|c|c|c|c|c|c|c|c|c|c|}
\hline \multirow{3}{*}{$\begin{array}{l}\text { Type of Households } \\
\text { and Farm Size }\end{array}$} & \multirow{3}{*}{$\begin{array}{c}\text { Number } \\
\text { of } \\
\text { House- } \\
\text { holds }\end{array}$} & \multirow{3}{*}{ Crops } & \multirow{3}{*}{$\begin{array}{l}\text { Machi- } \\
\text { nery }\end{array}$} & \multirow{3}{*}{$\begin{array}{c}\text { Milch } \\
\text { Animals }\end{array}$} & \multirow{3}{*}{$\begin{array}{l}\text { Live- } \\
\text { stock } \\
\text { Except } \\
\text { Milch } \\
\text { Animals }\end{array}$} & \multirow{3}{*}{ Labour } & \multirow{2}{*}{\multicolumn{2}{|c|}{$\begin{array}{l}\text { Cost Borne as } \% \text { of } \\
\text { Household Income } \\
\text { for }\end{array}$}} & \multirow{3}{*}{$\begin{array}{l}\text { Household } \\
\text { Income } \\
\text { Net of } \\
\text { Costs } \\
(\%)\end{array}$} & \multirow{3}{*}{$\begin{array}{c}\text { Average } \\
\text { House- } \\
\text { hold } \\
\text { Income } \\
\text { (Rs.) }\end{array}$} & \multirow{3}{*}{$\begin{array}{c}\text { Annua } \\
\text { per } \\
\text { Capita } \\
\text { Incom } \\
\text { (Rs) }\end{array}$} \\
\hline & & & & & & & & & & & \\
\hline & & & & & & & $\begin{array}{c}\text { Labour } \\
\text { (Nega- } \\
\text { tive } \\
\text { Income) }\end{array}$ & $\begin{array}{c}\text { Debt } \\
\text { (Nega- } \\
\text { tive } \\
\text { Income) }\end{array}$ & & & \\
\hline 1. All Households & 6254303 & 53.67 & 2.70 & 16.56 & 7.29 & 23.75 & -3.09 & -0.88 & 100 & 13245 & 1947.79 \\
\hline 2. Livestock Households & 1989708 & 0 & 0.78 & 18.37 & 8.14 & 74.33 & -0.96 & -0.65 & 100 & 9925 & 1550.78 \\
\hline 3. Farm Households & 4264594 & 70.57 & 3.32 & 15.86 & 7.03 & 7.93 & -3.77 & -0.95 & 100 & 14771 & 2110.14 \\
\hline Under 1.0 acre & 185604 & 16.68 & 0.64 & 22.54 & 8.07 & 53.63 & -0.42 & -1.14 & 100 & 4982 & 844.41 \\
\hline $1.0-2.5$ acres & 523560 & 36.86 & 0.50 & 24.07 & 10.70 & 29.47 & -0.71 & -1.08 & 100 & 6017 & 986.39 \\
\hline $2.5-5.0$ acres & 697618 & 53.75 & 0.24 & 22.61 & 9.72 & 16.51 & -0.95 & -0.87 & 100 & 7930 & 1239.06 \\
\hline $5.0-7.5$ acres & 703201 & 61.60 & 0.68 & 20.97 & 8.55 & 10.45 & -1.32 & -0.83 & 100 & 10031 & 1497.16 \\
\hline $7.5-12.5$ acres & 957558 & 67.07 & 0.99 & 18.93 & 8.32 & 7.36 & -1.82 & -0.84 & 100 & 18532 & 2438.42 \\
\hline $12.5-25.0$ acres & 765814 & 72.60 & 3.75 & 16.02 & 7.35 & 4.53 & 3.33 & 0.92 & 100 & 12710 & 1790.14 \\
\hline $25.0-50.0$ acres & 302428 & 77.69 & 6.28 & 11.76 & 5.60 & 2.61 & -2.89 & -1.05 & 100 & 30808 & 3711.81 \\
\hline $50.0-150.0$ acres & 112339 & 89.63 & 8.09 & 7.28 & 3.83 & 1.61 & -9.22 & -1.23 & 100 & 61374 & 6819.33 \\
\hline 150 acres and above & 16464 & 101.75 & 3.62 & 3.34 & 1.75 & 0.65 & -10.28 & -0.83 & 100 & 217086 & 20674.86 \\
\hline
\end{tabular}


Table 4

Growth in Average Yearly Household Income of Different Groups in Rural Sector of Pakistan for Selected Periods

Farm Size and

Household Type

\section{Farm Size}

Small Farms (12.5 Acres)

Medium Farms (12.5 - 50.0 Acres)

Large Farms (50 + Acres)

8.63

4.92

9.22

14.97

18.89

19.23

11.12

10.30

13.12

\section{Household Type}

Farm Households

Non-Farm Households

All Households

\begin{tabular}{rrr}
9.44 & 16.16 & 12.00 \\
3.28 & 15.47 & 7.99 \\
7.49 & 15.79 & 10.74 \\
\hline
\end{tabular}

Source: Pakistan $[18 ; 19 ; 20$ and 21] for Table 3 and Tables 1 to 3 for Table 4.

of the total income of the livestock households in 1960, which declined slightly to 72.55 percent in 1972 but went up again to 73.37 percent in 1980. Labour share in the income of farms with less than 5 acres of land was also quite high - up to 50 percent in some cases.

3. These estimates indicate that livestock are among the most important factors of rural income. In particular, milch animals contributed as much as 36 percent to the incomes of some farm groups in 1960 and up to 24 percent in 1980. The importance of livestock is further enhanced when the share of their non-milk products is also added to the income from milk.

4. Farm machinery was not a major contributor to the overall income of dif ferent farm groups. However, in the incomes of large farms its contribution was quite high. Even in 1960 when machinery contributed almost nothing to the incomes of small and medium farms (with farm size between 12.5 and 50 acres), its contribution to large farms' income was close to their income from labour. In 1980, after crops, farm machinery was the second major source of large farms' income.
5. As regards growth in income over time, farm households seem to have fared better than their non-farm counterparts. For example, between 1960 and 1972, farm households' income grew at the rate of 9.4 percent per annum, whereas for non-farm households the increase was only 3.28 percent per annum. Between 1972 and 1980 the situation remained very much the same: the income of the livestock households increased at the rate of 15.47 percent per annum whereas the income of farm households grew at the rate of 16.16 percent. ${ }^{14}$

6. As regards inter-farm growth rates, one observes a higher growth in the incomes of small farms than in those of medium and large farms between 1960 and 1972. During the 1972-80 period, incomes of medium and large farms grew faster than the income of small farms. During the whole 1960-80 period the large farms fared better than the other farm groups. Similarly, during the $1960-72$ period, farmers in the ' 150 acres and above' category had an edge over the other categories. This could be attributed to the growing share of income from machinery in the overall incomes of those households.

(b) Estimates of Income Inequality

Table 5 summarizes the estimates of Gini-coefficients for 'farm households' and 'all households' separately, based on the distribution of physical assets and income in Pakistan.

The upper part of the table shows 'Asset Ginis' (i.e. Ginis based on asset data) whereas the bottom part contains 'Income Ginis' (i.e. Ginis based on income data). The last two rows of the table show Gini coefficients for aggregate income, the last rows being based on the weighted sums of factor Ginis. ${ }^{15}$

The following are the most noteworthy observations from Table 5.

1. There is a highly positive relationship between Asset Ginis and Income Ginis in almost all the cases. This was very much expected as physical assets are the most important determinant of household income. However, an interesting result is that income Ginis in a number of cases are higher than asset-Ginis. This in particular is true for incomes from crops and machinery. In these two cases it seems that besides initial endowments, market and non-market institutions also played a significant role in increasing

${ }^{14}$ High growth rates during the Seventies were most probably due to the high rate of inflation experienced by Pakistan during that period.

${ }^{15}$ According to Fei, Ranis and Kuo [6] Gini coefficient of aggregated income $\left(G_{y}\right)$ is the weighted sum of the factor Gini-coefficients $(G I)$ where the distribution share $\left(W_{i}\right)$ are the weights; i.e. $G_{y}=W_{1} G_{1}+\mathrm{W}_{2} G_{2}+\ldots \ldots \ldots W_{i} G_{i}$ 
Table 5

Gini Coefficients Based on Rural Assets and Income Distribution in Pakistan 1960, 1972 and 1980

\begin{tabular}{|c|c|c|c|c|c|}
\hline \multicolumn{2}{|c|}{1960} & \multicolumn{2}{|c|}{1972} & \multicolumn{2}{|c|}{1980} \\
\hline Far & A & Farm & All & Farm & All \\
\hline $\begin{array}{l}\text { House- } \\
\text { holds }\end{array}$ & $\begin{array}{l}\text { House- } \\
\text { holds }\end{array}$ & $\begin{array}{l}\text { House- } \\
\text { holds }\end{array}$ & $\begin{array}{c}\text { House- } \\
\text { holds }\end{array}$ & $\begin{array}{l}\text { House- } \\
\text { holds }\end{array}$ & $\begin{array}{l}\text { House- } \\
\text { holds }\end{array}$ \\
\hline
\end{tabular}

(a) Ginis Based on Assets Distribution

\section{Assets/Liabilities}

1. Cropped Area

2. Tractors

3. Threshers/Shellers

4. Tubewells

5. Work Animal plus Dry Cows and Buffaloes

6. Sheep and Goats

7. Milch Animals

8. Poultry Birds

9. Labour Rented Out to:

(a) Agriculture Sector

(b) Non-Agriculture Sector

$\begin{array}{cccccc}0.529 & 0.598 & 0.393 & 0.561 & 0.430 & 0.611 \\ \text { NA } & \text { NA } & 0.772 & 0.769 & 0.678 & 0.696 \\ \text { NA } & \text { NA } & \text { NA } & \text { NA } & 0.733 & 0.765 \\ 0.416 & 0.501 & 0.509 & 0.566 & 0.534 & 0.562 \\ & & & & & \\ 0.258 & 0.265 & 0.067 & 0.167 & 0.211 & 0.321 \\ 0.290 & 0.174 & 0.194 & 0.116 & 0.211 & 0.108 \\ 0.227 & 0.170 & 0.099 & 0.058 & 0.177 & 0.134 \\ 0.132 & 0.110 & 0.067 & -0.042 & 0.204 & -0.001 \\ & & & & & \\ \text { NA } & \text { NA } & -0.130 & -0.481 & -0.147 & -0.462 \\ \text { NA } & \text { NA } & -0.176 & -0.480 & -0.178 & -0.457\end{array}$

10. Credit (Debt)

$\begin{array}{llllll}0.376 & 0.468 & \text { NA } & \text { NA } & 0.381 & 0.354\end{array}$

(b) Ginis Based on Income Distribution

\section{Sources of Income}

1. Crops

2. Machinery

3. Milch Animals

4. Livestock (Except Milch Aniamls)

5. Labour

6. Cost of Debt

7. Cost of Labour

8. Aggregate Income

9. Aggregate Income (Weighted Sum)

$\begin{array}{rrrrrr}0.543 & 0.610 & 0.393 & 0.561 & 0.469 & 0.638 \\ 0.416 & 0.501 & 0.735 & 0.718 & 0.749 & 0.722 \\ 0.221 & 0.169 & 0.098 & 0.059 & 0.177 & 0.140 \\ & & & & & \\ 0.256 & 0.184 & 0.131 & 0.119 & 0.210 & 0.157 \\ -0.183 & -0.504 & -0.169 & -0.479 & -0.174 & -0.458 \\ 0.376 & 0.467 & 0.320 & 0.312 & 0.381 & 0.354 \\ 0.638 & 0.578 & 0.580 & 0.579 & 0.696 & 0.674 \\ 0.344 & 0.206 & 0.291 & 0.231 & 0.355 & 0.263 \\ & & & & & \\ 0.346 & 0.208 & 0.290 & 0.234 & 0.358 & 0.261\end{array}$

income inequality. This phenomenon, however, is not very obvious in the case of the income from labour, probably because the Ginis for this income source were based on 'total income from labour' whereas asset Ginis here were estimated separately for agricultural and non-agricultural labour. In all other cases, the two types of Ginis were very close mainly because income figures were derived exactly in proportion to the assets held by different households.

2. The decomposition of income Ginis presents a very complex picture of income inequality in the rural sector of Pakistan. First of all, one observes a decline in inequality in the overall income between 1960 and 1972 in the case of the estimates for farm households. The same trend emerges from labour becoming less favourable to small farms and livestock houseof all households (both farm and non-farm households), the estimates indicate that inequality increased in the $1960-72$ period. The value of the Gini coefficient for overall income increased from .206 in 1960 to .231 in 1972. This is one of the most interesting findings so far as it goes against the findings based on the data of the Household and Expenditure Surveys used by Ayub [1] , Chaudhry [3], Cheema [4] and Naseem [17]. This also goes against the findings based on data on physical assets or those based on the estimates for the farm households alone.

An explanation of this result can be found in the values of factorincome Ginis. Whereas for factors such as crops, milk and livestock, even the estimates for all households show a decline in inequality, the Ginis for other four factors - machinery, labour, debt and cost of labour convey the opposite. Looking more carefully, one finds a decline in the (negative) Gini for labour, which shows the distribution of the income from labour becoming less favourable to small farms and livestock households. Similarly; a decline in the Ginis for the costs of labour and debt implies greater costs to the small farms. Above all, the Ginis for the income from machinery were larger in 1972 than in 1960. All these factors seem to have offset the equality-inducing effects of other factors.

These results, however, do not necessarily go against those findings according to which during the Sixties small farms income increased more than that of other farm categories. In our estimates also income inequality among farm households show a decline between 1960 and 1972. What these results point to is that the non-farm households might have benefited somewhat less during the $1960-72$ period, resulting in an increase in the Ginis based on data for all households.

3. Between 1972 and 1980 , all indicators suggest an increase in income inequality. The Gini values for overall income increased from .291 in 
1972 to .355 in 1980 for farm households and from .231 in 1972 to .263 in 1980 for all households. There is a similar trend in the Ginis for factor-incomes.

4. The major inequality-augmenting factors appear to be cropped area and farm machinery. Employment and livestock are the two main inequality-mitigating factors. Two other minor factors which also seem to have decreased inequality are 'cost of debt' and labour. Both of these factors have quite high Ginis implying that the upper farm groups bore more cost burden than the small farms. ${ }^{16}$

5. The overall income inequality does not seem to be as high as indicated by some earlier estimates. In our estimates it is .201 for 1960 and .263 for 1980 whereas it was estimated by Ayub [1] to be as high as .357 in 1963 and .312 in 1971-72. Two factors might explain this: (i) while estimating income from labour from non-agricultural sources, wage rates used by us were weighted averages of wages in the manufacturing sector, so that it may well have understated the income of large farms whose members, if employed in non-agricultural sector, usually work in high-paying positions; and (ii) agricultural censuses by leaving out households possessing no assets, might have excluded from their data the "very poor" people, resulting in small values of income Ginis.

\section{CONCLUSIONS}

Owing to the preliminary nature of our estimates, only tentative conclusions can be offered at this stage. Firstly, it seems obvious that income distribution in Pakistan is not determined by any one factor, howsoever important it may be. Land is an important factor but livestock are no less important. Therefore, there is a need to attack income inequality from different directions. Secondly, though initial endowments are very important in determining household income, institutional forces (which influence the pricing of different assets, tenancy relations, and the magnitude and direction of income transfer within households) also seem to play an important role in this process. Therefore, some degree of inequality can be reduced if suitable changes are made in these institutions. Finally, it appears that in the Sixties small farms gained proportionately more but this might not have been the case with all the low-income categories. Livestock households do not seem to have fared very well probably because of a slow increase in employment opportunities.

${ }^{16}$ Farm credit, however, is a double-edged sword. Access to subsidized institutional credit is a source of an increase in farm income. Therefore, if large farms pay more interest on loan they may also benefit more from such loans.
Before concluding however we may point out a few weaknesses in our estimates. First of all, one can never be sure of the data available in a country such as Pakistan. Censuses data are relatively good but their comparability over time is nonetheless doubtful. Similarly, various prices and discounting factors (such as operating costs, and depreciation charges) used in our computations were gathered from more than one source. This may have introduced some bias in our calculations here and there. Finally, the income estimates obtained by us were aggregate for different groups which marked intra-group income differences. For example, in a given group incomes of those households who own tractors or tubewells are usually much higher than the income of those households who do not hold such assets. Our estimates, therefore, can not be used for arriving at a precise number of persons below a particular income level. To be able to do this one has to classify households by their ownership of different assets within each category and then estimates their incomes. This is a task which one may undertake in a future exercise.

\section{REFERENCES}

1. Ayub, M. A. "Sources and Structure of Income Inequality in Pakistan". A Paper Contributed in First Annual General Meeting of the Pakistan Society of Development Economists, Islamabad. March 1984.

2. Chaudhry, M. A. "Determination of Cost of Tubewell Water and Estimation of Economic Rent in Canal Irrigation”. Pakistan Development Review. Vol. XVII, No. 2. Summer 1978.

3. Chaudhry, M. Ghaffar. "Green Revolution and Redistribution of Rural Income: Pakistan's Experience”. Pakistan Development Review. Vol. XXII, No. 3. Autumn 1982.

4. Cheema, Aftab A. "An Analysis of Income Inequality and Some MacroEconomic Implications of Income Redistribution: A Case of Pakistan". Ph.D. Dissertation, University of Cincinnati. 1983.

5. Ercelawn, Aly. "Income Inequality in Rural Pakistan: A Study of Sample Villages". Pakistan Journal of Applied Economics. Summer 1984.

6. Fei, J., G. Ranis and S. Kuo. Growth with Equity: The Taiwan Case. New York: Oxford University Press. 1979.

7. Hussain, Akmal. "Changes in Agrarian Structure and Demand for Labour". In Employment and Structural Changes in Pakistan - Issues for the Eighties. ILO-ARTEP Report for the Pakistan Planning Commission. January 1983.

8. Irfan, M., and R. Amjad. "Poverty in Rural Pakistan". In A.R. Khan, and E. Lee. (eds.), Poverty in Rural Asia. Geneva: ILO. 1983.

9. Khan, M. H. The Economics of the Green Revolution in Pakistan. New York: Praeger Publishers. 1975.

10. Khan, M. H. Underdevelopment and Agrarian Structure in Pakistan. Boulder: Colorado: Westview Press. 1981. 
11. Khan, M. H. Lectures on Agrarian Transformation in Pakistan. Islamabad: Pakistan Institute of Development Economics. 1985 (Lecture No. 4 in the Lectures in Development Economics Series)

12. Khandekar, R. "Distribution of Income and Wealth in Pakistan". Pakistan Economics and Social Review. Spring 1973.

13. Mahmood, Z. "Income Inequality in Pakistan: An Analysis of Existing Evidence". A paper presented at the First Annual General Meeting of the Pakistan Society of Development Economists. Islamabad. 1984.

14. Mohammad, Faiz. "Rural Income Distribution in Pakistan: A Synthesis". A Report Submitted to the Ministry of Food and Agriculture, Government of Pakistan. 1984.

15. Muhammad, G. "Private Tubewell Development and Cropping Patterns in West Pakistan". Pakistan Development Review. Vol. V, No. 1. Spring 1965.

16. Naqvi, Syed Nawab Haider et al. The P.I.D.E. Macro-econometric Model of Pakistan's Economy. Islamabad: Pakistan Institute of Development Economics. 1983.

17. Naseem, S. M. Underdevelopment, Poverty and Inequality in Pakistan. Lahore: Vanguard Publications Ltd. 1981.

18. Pakistan. Agricultural Census Organization. Pakistan Census of Agriculture. Lahore. (1960, 1972 and 1980 Reports)

19. Pakistan. Ministry of Food and Agriculture (Planning Unit). Cost of Production: A Comparative Study of Different Crops. Islamabad. February 1979.

20. Pakistan. Ministry of Food and Agriculture (Planning Unit). Agricultural Statistics of Pakistan, 1982. Islamabad. 1983.

21. Pakistan. Ministry of Finance. Economic Adviser's Cell. Pakistan Economic Survey. Islamabad. 1982-83.

2. Pakistan. Federal Bureau of Statistics. 25 Years of Pakistan in Statistics 1947-1972. Karachi. 1972.

:3. Pakistan. Federal Bureau of Statistics. Household Income and Expenditure Survey 1971-72. Karachi. 1972.

:4. Pakistan Institute of Public Opinion (PIPO). National Survey (unpublished). Islambad. 1981.

5. Punjab Economic Research Institute. Workshop on the Economics of Village Livestock. Lahore. May 1981.

6. Szal, Richard, and Sherman Robinson. "Measuring Income Inequality". In Charles R. Frank and Richard C. Webb. (eds.), Income Distribution and Growth in Less Developed Countries. Washington, D.C.: The Brookings Institution. 1977. 
farm income accruing to the operator, but also the level of income for a given $\mathrm{rm}$ size. The level of yield per acre on owner-operated and tenant-operated farms ould differ because they constitute two different forms of production organizaon. The tenant's capacity and incentive to invest are much lower than those of e farm owner. His access to credit and other inputs is poor because of his weak cial position and poor collateral. Finally, the timing of input availability, which s been shown to be so important in determining yields, is far poorer for the tenant an for the owner-operator. Thus step 2 of the authors - that of halving the inme of tenants - would seriously overstate tenant's income from crops.

3. The authors have imputed income to various farm categories on the basis their estimate of tractor use and tractor ownership. They have not indicated at all ow their estimate of net imputed income from tractor use separates the effect of actors from other inputs like water, tubewells, and such factors as cropping intensies and cropping patterns. Evidence shows that in South Asia tractors themselves do t raise yields except by increasing cropping intensities in cases where the labour nstraint is critical. But, then, cropping intensity on small family farms could be ised without tractors. Such specification problems need at least to be mentioned in e text before an estimate of income from the use of tractors is offered.

4. In imputing income from livestock by farm size, the authors use simply the nsus figures on the numbers of animals by farm size, and a fixed production estiate of beef etc. per animal. Such a procedure ignores the fact that the proporon of sheep, goats, cows, buffaloes, etc., that are actually slaughtered would vary nsiderably by farm size. Perhaps equally important is the fact that the weight of ese animals which is implicitly assumed by the authors to be constant across $\mathrm{rm}$ size would actually vary considerably. The variation in the weight of animals ould occur particularly between tenant- and owner-operated farms, where the ility to feed the animals adequately would differ and the intensity of work to hich the animals are subjected would vary, given the differing cropping intensities the two forms of production organization.

5. The most hazardous component of income that the authors have imputed various farm categories is the income from labour. This is so on a whole range of ounds. Let me mention only three.

(i) Estimation of income from labour has to take account of the fact that the concept of wage is a fragile category in an economy where capitalist production relations are synthesized in a complex way with feudal relations. Thus, the composition of "wage" in terms of cash, kind, and, most importantly, indirect considerations varies considerably both between farms sizes and within each farm size category. If the tenant is tied to the landlord by extra economic dependence, certain labour services would be performed free of charge, or at wages below the ruling market wages. (For a detailed discussion of forms of wage payment and control of labour, see my D. Phil Thesis, Sussex, 1980.)

(ii) The cost of labour as well as the monthly wage rate varies considerably across different forms of production organization, because of the complexity of the wage relation in a social formation like Pakistan.

(iii) Labour income would be a function not only of the wage rate but also of the period over which the labourer is employed. This crucial determinant is heroically assumed by the authors without mentioning the basis of their assumption.

Consultant Economist,

Dr Syed Akmal Hussain M. D. Sayyed Engineers, Lahore 